\title{
Vitamin D levels in an Australian and New Zealand cohort and the association with pregnancy outcome
}

Rebecca L. Wilson 1,2, Alison J. Leviton 1,2, Shalem Y. Leemaqz ${ }^{1,2}$, Paul H. Anderson³, Jessica A. Grieger 1,2, Luke E. Grzeskowiak ${ }^{1,2}$, Petra E. Verburg ${ }^{1,2,4}$, Lesley McCowan ${ }^{5}$, Gustaaf A. Dekker ${ }^{1,6}$, Tina Bianco-Miotto ${ }^{1,7}$ and Claire T. Roberts ${ }^{1,2^{*}}$ (iD

\begin{abstract}
Background: Pregnant women are at increased susceptibility to vitamin D deficiency. Hence, there is continuing interest in determining how vitamin D influences pregnancy health. We aimed to compare vitamin $D$ status in two distinct populations of pregnant women in Australia and New Zealand and to investigate the relationship between vitamin D status and pregnancy outcome. This included evaluating possible effect measure modifications according to fetal sex.
\end{abstract}

Methods: Serum 25-hydroxy vitamin D $(25(\mathrm{OH}) \mathrm{D})$ was measured at $15 \pm 1$ weeks' gestation in 2800 women from Adelaide and Auckland who participated in the multi-centre, prospective cohort SCreening fOr Pregnancy Endpoints (SCOPE) study.

Results: Mean serum 25(OH)D in all women was $68.1 \pm 27.1 \mathrm{nmol} / \mathrm{L}$ and $28 \%(n=772)$ were considered vitamin $\mathrm{D}$ deficient $(<50 \mathrm{nmol} / \mathrm{L}$ ). Serum 25(OH)D was lower in the women recruited in Adelaide when compared to the women recruited in Auckland and remained lower after adjusting for covariates including maternal body mass index and socioeconomic index (Adelaide: $58.4 \pm 50.3$ vs. Auckland: $70.2 \pm 54.5 \mathrm{nmol} / \mathrm{L}, P<0.001$ ). A $53 \%$ decreased risk for gestational diabetes mellitus (GDM) was observed with high ( $>81 \mathrm{nmol} / \mathrm{L}$ ) "standardised" vitamin D status when compared to moderate-high (63-81 nmol/L, aRR, 0.47; 95\% Cl: 0.23, 0.96). Marginal sex-specific differences occurred between vitamin D status and GDM: women carrying a female fetus had a 56\% decreased risk for GDM in those with low-moderate levels of standardised vitamin $D(44-63 \mathrm{nmol} / \mathrm{L})$ compared to moderate-high levels (aRR: $0.44 ; 95 \% \mathrm{Cl}$ : 0.20, 0.97), whilst in women carrying a male fetus, a 55\% decreased risk of GDM was found with high standardised vitamin $\mathrm{D}$ when compared to moderately-high vitamin $\mathrm{D}$, but this was not statistically significant (aRR: $0.45 ; 95 \% \mathrm{Cl}: 0.15,1.38)$.

Conclusions: High serum $25(\mathrm{OH}) \mathrm{D}$ at $15 \pm 1$ weeks' gestation was shown to be protective against the development of GDM. A possible association between fetal sex, vitamin D status and GDM provides further questions and encourages continual research and discussion into the role of vitamin D in pregnancy, particularly in vitamin $D$ replete populations.

Keywords: Vitamin D, Pregnancy, Pregnancy outcome, Gestational diabetes mellitus, Fetal sex

\footnotetext{
* Correspondence: claire.roberts@adelaide.edu.au

${ }^{1}$ Robinson Research Institute, University of Adelaide, Adelaide, South

Australia, Australia

${ }^{2}$ Adelaide Medical School, University of Adelaide, Adelaide, South Australia,

Australia

Full list of author information is available at the end of the article
}

(c) The Author(s). 2018 Open Access This article is distributed under the terms of the Creative Commons Attribution 4.0 International License (http://creativecommons.org/licenses/by/4.0/), which permits unrestricted use, distribution, and reproduction in any medium, provided you give appropriate credit to the original author(s) and the source, provide a link to the Creative Commons license, and indicate if changes were made. The Creative Commons Public Domain Dedication waiver (http://creativecommons.org/publicdomain/zero/1.0/) applies to the data made available in this article, unless otherwise stated. 


\section{Background}

With an increasing prevalence of vitamin D deficiency and insufficiency reported both in Australia and New Zealand, as well as worldwide [1], there is continuing interest in determining how vitamin D deficiency may influence health in pregnancy. Evidence suggests that vitamin D deficiency is associated with a number of pregnancy complications including preeclampsia (PE), gestational diabetes mellitus (GDM) and spontaneous preterm birth (sPTB) [2-4]. However, inconsistencies between studies reflect uncertainty about the true effect of vitamin $\mathrm{D}$ deficiency on pregnancy outcome $[5,6]$. This may be explained, in part, by inadequate control of related risk factors and confounders in statistical analyses, variations between assays that measure vitamin $\mathrm{D}$ and significant heterogeneity between studied populations [6].

Vitamin D status is determined by measuring circulating serum levels of 25-hydroxy vitamin $\mathrm{D}_{2+3}(25(\mathrm{OH}) \mathrm{D})$. In Australia and New Zealand, the deficiency cut-offs are based on the role of vitamin $\mathrm{D}$ in bone health where serum $25(\mathrm{OH}) \mathrm{D} \geq 50 \mathrm{nmol} / \mathrm{L}$ at the end of winter is required for optimal musculoskeletal health [1]. Furthermore, it has been established that serum $25(\mathrm{OH}) \mathrm{D} \geq 50 \mathrm{nmol} / \mathrm{L}$ is $\mathrm{rec}-$ ommended during pregnancy and lactation [7]. The incidence of vitamin D deficiency ( $<50 \mathrm{nmol} / \mathrm{L})$ is frequent among pregnant women even in areas such as Australia and the North Island of New Zealand where sunlight exposure is high. Studies focused on high-risk populations, for example, veiled, dark-skinned or obese women in Australia and New Zealand, report between 50 and 94\% of women to be vitamin D deficient [8-10]. Reports from lower-risk groups have indicated that vitamin $\mathrm{D}$ deficiency occurs in $25-55 \%$ of pregnant women [11-13].

There are numerous studies which have shown that vitamin $\mathrm{D}$ deficiency is associated with adverse pregnancy outcomes (Most recent: [14-17]), particularly in populations that reside at higher latitudes. However, studies in women from Australia and New Zealand are less consistent. Previous studies on pregnant Australian and New Zealand women have reported that while circulating 25(OH)D was significantly lower in women with PE, sPTB, GDM and those who delivered a small-for gestational age (SGA) infant, no association between vitamin $\mathrm{D}$ deficiency and these pregnancy complications was found after adjusting for covariates [18-20]. Differences in ethnicity [21], solar exposure and geographical location, as well as genetics [22] and supplementation [23-25], are known to affect $25(\mathrm{OH}) \mathrm{D}$ status and therefore influence study outcomes. Furthermore, the gestation at which vitamin $\mathrm{D}$ was measured is also important. In the case of preterm delivery, vitamin D status measured closer to the delivery date was more significantly associated with preterm delivery than earlier measures [26]. However, measuring circulating 25(OH)D in early pregnancy is common and potentially clinically useful as this is prior to when many of the pregnancy complications that affect late gestation manifest.

Using a robust, validated chemiluminescent-based assay to measure serum 25(OH)D [27], we aimed to investigate the differences between vitamin D status in early pregnancy in two distinct populations of nulliparous women from Australia and New Zealand. We also aimed to examine the relationship between serum 25(OH)D at $15 \pm$ 1 weeks' gestation and the risk of an adverse pregnancy outcome and included determining the effect modification of fetal sex on the association between maternal vitamin D status and pregnancy outcome.

\section{Methods}

\section{Study population}

This study utilised data collected from the multi-centre, prospective cohort Screening for Pregnancy Endpoints (SCOPE) study [28]. Nulliparous women carrying a singleton pregnancy were recruited between November 2004 and September 2008 in Adelaide (Australia) and Auckland (New Zealand). Ethics approval was obtained from Central Northern Adelaide Health Service Ethics of Human Research Committee on 2 September 2005 (ethics number REC 1714/5/2008) and Northern Region Ethics Committee, in Auckland on 23 April 2003 (ethics number AKX/02/00/364). All participants provided written informed consent. At $15 \pm 1$ weeks' gestation, women were interviewed by a research midwife and asked questions on maternal demographics and lifestyle and had physical measurements taken, including height and weight. Records included ethnicity, age, body mass index (BMI), socioeconomic index (SEI) and multivitamin use [29]. BMI was calculated as weight $(\mathrm{kg}) /$ height $^{2}\left(\mathrm{~m}^{2}\right)$. Obesity was defined as BMI $\geq 30 \mathrm{~kg} / \mathrm{m}^{2}$, overweight as BMI $\geq 25$ and $<30 \mathrm{~kg} / \mathrm{m}^{2}$, normal weight as BMI $>20$ and $<25 \mathrm{~kg} / \mathrm{m}^{2}$ and underweight as BMI $\leq 20 \mathrm{~kg} / \mathrm{m}^{2}$. SEI was calculated using the New Zealand SEI of occupational status, deriving a number between 10 and 90 based on the woman's occupation; a higher number indicates higher socioeconomic status [30]. This population of women was predominantly Caucasian and thus maternal ethnicity was categorised into 2 main groups; Caucasian and non-Caucasian. Uncomplicated pregnancies were defined as those without any pregnancy disorder who delivered an appropriate weight for gestational age infant at term ( $\geq 37$ weeks gestation) [31]. Pregnancy complications studied included PE, gestational hypertension $(\mathrm{GH})$, GDM, sPTB and SGA and have been previously defined [28, 29, 31, 32].

\section{Measurement of serum 25(OH)D}

Non-fasting whole peripheral blood samples were collected into non-heparinised tubes at $15 \pm 1$ weeks' gestation. Serum 
was processed within $4 \mathrm{~h}$ of collection and stored at $-80^{\circ}$ $\mathrm{C}$ until required. Unlike the previously published data on vitamin D in the Auckland cohort [20], serum 25(OH)D was measured using the IDS-iSYS chemiluminescent-based assay (Abacus, ALS) as per the manufacturer's instructions. Average intra- and inter-assay coefficient of variation (CV) were 5.4 and $8.8 \%$, respectively. Both serum $25(\mathrm{OH}) \mathrm{D}_{3}$ and $25(\mathrm{OH}) \mathrm{D}_{2}$ were measured independently and combined to provide a total $25(\mathrm{OH}) \mathrm{D}$ in $\mathrm{nmol} / \mathrm{L}$ [27].

\section{Statistical analyses}

Statistical analyses were performed in R (v3.1.1) [33]. Data were checked for normality using a Shapiro-Wilks test and differences between women recruited in Adelaide compared to Auckland were tabulated and compared using a Welch's t-test (continuous variables) or Fisher's exact test (categorical variables).

Given that the month in which the serum was sampled heavily influences vitamin D status, "standardised" serum $25(\mathrm{OH}) \mathrm{D}$ concentrations were calculated as previously described [34] in order to normalise against seasonal variation. Briefly, vitamin D concentrations were standardized by taking the difference of $25(\mathrm{OH}) \mathrm{D}$ concentration to the average $25(\mathrm{OH}) \mathrm{D}$ concentration of the corresponding month. This $25(\mathrm{OH}) \mathrm{D}$ concentration was then added to the overall population mean $25(\mathrm{OH}) \mathrm{D}$ concentration: $68.09 \mathrm{nmol} / \mathrm{L}$. Quartiles, based on the distribution amongst the population of women studied, in the standardised concentrations were then used to create cut-points and designated 'low' (<44 nmol/L), 'low-moderate' (44-63 nmol/L), 'moderate-high' (63$81 \mathrm{nmol} / \mathrm{L}$ ) and 'high' (> $81 \mathrm{nmol} / \mathrm{L}$ ) categories of serum 25(OH)D.

Generalised linear models (Poisson with log link and robust variance estimates) were used to calculate the risk ratios for pregnancy complications by standardised serum $25(\mathrm{OH}) \mathrm{D}$ concentrations calculated among the women who had an uncomplicated pregnancy. Potential confounders for vitamin D status were assessed using linear modelling. Maternal age, BMI, SEI, alcohol consumption at $15 \pm 1$ weeks' gestation (never/former vs. current), recreational walking (1-3 times/week and $\geq 4$ times/week vs. never), ethnicity (Caucasian vs. non-Caucasian) and recruitment site (Adelaide vs. Auckland) were significantly associated with serum $25(\mathrm{OH}) \mathrm{D}$ and along with smoking status at $15 \pm 1$ weeks' gestation (never/former vs. current) included as main effects within the generalised linear models. These analyses were also repeated but using the current definitions of vitamin D deficiency: <25, 25-50, 50-75 and $>75 \mathrm{nmol} / \mathrm{L}$ in the non-standardised data [7]. We also stratified based on fetal sex to evaluate possible effect measure modifications according to whether the mother was carry a male or female fetus.

\section{Results}

\section{Population characteristics}

Of 3229 women recruited as part of SCOPE at the Adelaide and Auckland centres, serum samples at $15 \pm$ 1 weeks' gestation to measure $25(\mathrm{OH}) \mathrm{D}$ were available for $2800(87 \%)$ women of whom, 1156 (41\%) were recruited in Adelaide and 1644 (59\%) were recruited in Auckland. Maternal characteristics are shown in Table 1. Compared to women who were recruited at the Adelaide site, women recruited in Auckland were older, had a lower BMI, less likely to smoke or drink alcohol during pregnancy and more likely to eat fruit and undertake recreational walks. Mean \pm SD SEI of the Auckland women was also higher compared to that in women recruited in Adelaide (Auckland: $48.0 \pm 14.8$ vs. Adelaide: $27.7 \pm 10.5, P<0.001)$. Given that all these factors significantly influenced serum $25(\mathrm{OH}) \mathrm{D}$ in the linear regression model, it was unsurprising that vitamin $\mathrm{D}$ status of the women was significantly different between the two recruitment sites. However, after adjusting for maternal age, BMI, SEI, smoking status and alcohol consumption at $15 \pm 1$ weeks' gestation, ethnicity, recreational walking and season, the women recruited in Adelaide still had significantly lower serum 25(OH)D when compared with those in Auckland (Adelaide: $58.4 \pm 50.3$ vs. Auckland: $70.2 \pm 54.5 \mathrm{nmol} / \mathrm{L}, \mathrm{P}<0.001)$ indicating the influence of other confounders not measured as part of the study on vitamin $\mathrm{D}$ status.

\section{Standardising serum 25(OH)D based on seasonal variation}

As expected, there was a seasonal influence on serum $25(\mathrm{OH}) \mathrm{D}$ and thus, "standardised" vitamin D concentrations were calculated to account for the month of serum collection. Average hours of sunlight per day in Adelaide from September 2005 to September 2008 were obtained from the Australian Government Bureau of Meteorology and compared against serum vitamin $\mathrm{D}$ measured in the women recruited in Adelaide (Fig. 1a; black line/left axis serum $25(\mathrm{OH}) \mathrm{D}$ and grey line/right axis average hours of sunlight). The means for serum 25(OH)D by month of sampling were also separated for women recruited in Adelaide and women recruited in Auckland (Fig. 1b).

\section{Serum 25(OH)D and pregnancy outcome}

Of the 2800 women present in this study, 1217 (43\%) women went on to develop a pregnancy complication and included 5.8\% ( $n=161)$ who developed PE, 7.6\% $(n=213)$ who developed GH, 3.3\% ( $n=92)$ who developed GDM, $5 \%(n=139)$ who spontaneously delivered preterm and $10.6 \%(n=298)$ who delivered an SGA infant.

The association between "standardised" 25(OH)D with pregnancy complications is presented in Table 2. Using moderate-high as a reference (standardised vitamin D 
Table 1 Participant characteristics and comparison of characteristics between women recruited at the Adelaide and Auckland SCOPE centres

\begin{tabular}{|c|c|c|c|c|}
\hline & All women $(n=2800)$ & Adelaide $(n=1156)$ & Auckland $(n=1644)$ & $P$ value* \\
\hline Age yrs, mean (SD) & $28(6)$ & $23.73(5.11)$ & $30.44(4.82)$ & $<0.0001$ \\
\hline BMI kg/m², mean (SD) & $25.8(5.44)$ & $27.04(6.56)$ & $24.88(4.26)$ & $<0.0001$ \\
\hline Ethnicity & & & & $<0.0001$ \\
\hline Caucasian & $2449(87)$ & $1060(92)$ & $1389(84)$ & \\
\hline Non Caucasian & $351(13)$ & $96(8)$ & $255(16)$ & \\
\hline Smoking status, n (\%) & & & & $<0.0001$ \\
\hline No & $2152(77)$ & $704(61)$ & $1448(88)$ & \\
\hline Quit during pregnancy & $306(11)$ & $175(15)$ & $131(8)$ & \\
\hline Smoking & $342(12)$ & $277(24)$ & $65(4)$ & \\
\hline Alcohol Consumption, n (\%) & & & & $<0.0001$ \\
\hline No & $1480(53)$ & $708(61)$ & $772(47)$ & \\
\hline Stopped during pregnancy & $1185(42)$ & $397(34)$ & $788(48)$ & \\
\hline Consuming alcohol & $135(5)$ & $51(4)$ & $84(5)$ & \\
\hline Fruit Intake, n (\%) & & & & $<0.0001$ \\
\hline$\geq 1 \times$ per day & $2032(73)$ & $586(51)$ & $1446(88)$ & \\
\hline 3-6x per week & $405(14)$ & $272(24)$ & $133(8)$ & \\
\hline 1-2x per week & $223(8)$ & $181(16)$ & $42(3)$ & \\
\hline $1-3 x$ per month or less & $140(5)$ & $117(10)$ & $23(1)$ & \\
\hline Recreational Walking & & & & $<0.0001$ \\
\hline Never & $428(15)$ & $265(23)$ & $163(10)$ & \\
\hline 1-3 times/week & $1773(63)$ & $668(58)$ & $1105(68)$ & \\
\hline$\geq 4$ times/week & $590(22)$ & $221(19)$ & $369(23)$ & \\
\hline Time watching TV & & & & $<0.0001$ \\
\hline$<5$ hours per day & $2404(86)$ & $901(78)$ & $1503(92)$ & \\
\hline$\geq 5$ hours per day & $387(14)$ & $253(22)$ & $134(8)$ & \\
\hline Season serum was sampled & & & & 0.3213 \\
\hline Summer & $636(23)$ & $278(24)$ & $358(22)$ & \\
\hline Autumn & $705(25)$ & $273(24)$ & $432(26)$ & \\
\hline Winter & $727(26)$ & $300(26)$ & $427(26)$ & \\
\hline Spring & $732(26)$ & $305(26)$ & $427(26)$ & \\
\hline Serum 25(OH)D nmol/L, mean (SD) & $68.09(27.14)$ & $60.06(23.68)$ & $73.74(27.99)$ & $<0.0001$ \\
\hline Vitamin D Status & & & & $<0.0001$ \\
\hline$<25 \mathrm{nmol} / \mathrm{L}$ & $99(4)$ & $48(4)$ & $51(3)$ & \\
\hline $25-50 \mathrm{nmol} / \mathrm{L}$ & $673(24)$ & $375(32)$ & $298(18)$ & \\
\hline $50-75 \mathrm{nmol} / \mathrm{L}$ & $928(33)$ & $422(37)$ & $506(31)$ & \\
\hline$>75 \mathrm{nmol} / \mathrm{L}$ & 1098 (39) & $311(27)$ & 787 (48) & \\
\hline
\end{tabular}

${ }^{*} P$ values for continuous variables were determined using a Welch's t-test and categorical variables a Fisher's exact test comparing Adelaide and Auckland women

63-81 nmol/L), there was no appreciable effect of having a low, low-moderate or high vitamin $\mathrm{D}$ with the risk of developing any pregnancy complication after adjusting for confounders. However, when each pregnancy complication was analysed separately, a $53 \%$ decreased risk for GDM was observed with high vitamin D status when compared to moderate-high status (aRR: 0.47; 95\%
CI: $0.23,0.96)$. When women were categorised based on clinical definitions of vitamin $\mathrm{D}$ deficiency and serum $25(\mathrm{OH}) \mathrm{D}$ between 50 and $75 \mathrm{nmol} / \mathrm{L}$ used as the reference, no significant relationship between vitamin D status and adverse pregnancy outcome was found (Table 2). Although, the point estimates indicated a marginal increased risk for developing any pregnancy complication 


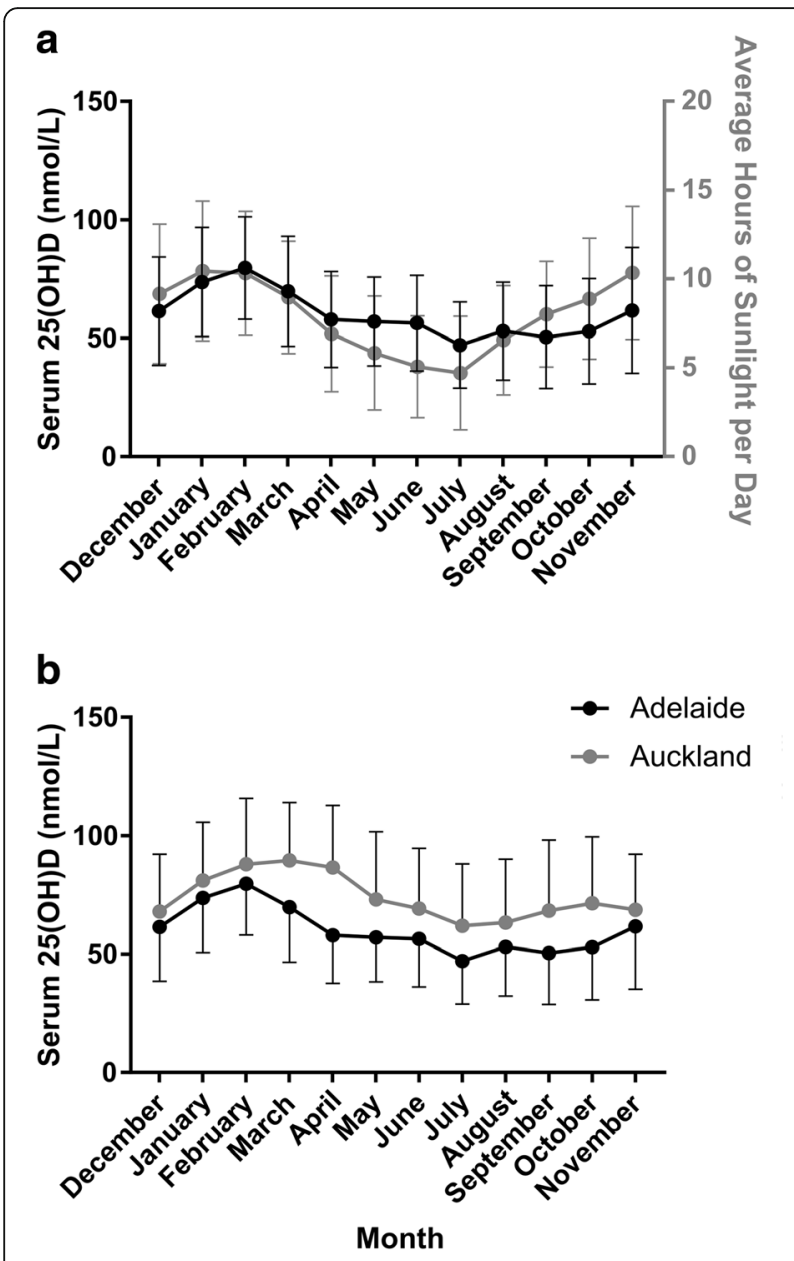

Fig. 1 Seasonal variation in serum 25(OH)D. a. Comparison of serum 25(OH)D levels based on month of sampling in the women recruited in Adelaide (black line \& left axis) and average hours of sunlight per day in Adelaide (grey line \& right axis). Seasonal variation in vitamin $D$ followed a similar pattern to hours of sunlight although was slightly shifted. $\mathbf{b}$. Seasonal variation of serum $25(\mathrm{OH}) \mathrm{D}$ based on month of sampling between women recruited in Adelaide compared to Auckland. Data are mean \pm SD

with severe $(<25 \mathrm{nmol} / \mathrm{L})$ vitamin $\mathrm{D}$ deficiency compared to those who had levels between 50 and $75 \mathrm{nmol} /$ L (aRR: 1.10; 95\% CI: 0.89, 1.36).

\section{Serum 25(OH)D, pregnancy outcome and fetal sex}

As there is evidence to suggest that vitamin D metabolism within the placenta may differ with respect to fetal sex [35] thus, we assessed the effect of "standardised" vitamin $\mathrm{D}$ status on pregnancy outcome stratified by fetal sex (Table 3). Although not statistically significant, point estimates for women carrying a male fetus indicated decreased risk of having any pregnancy complication with high serum 25(OH)D compared to moderately-high (aRR: $0.86 ; 9 \% \%$ CI: $0.71,1.04)$. This was largely driven by a $55 \%$ decreased risk of GDM in women with a male fetus with high standardised serum 25(OH)D when compared to those carrying a male fetus with moderate-high serum 25(OH)D (aRR: 0.45; 95\% CI: 0.15, 1.38). Conversely, if a woman was carrying a female fetus, there was generally no effect of having low, low-moderate or high standardised serum $25(\mathrm{OH}) \mathrm{D}$ on developing any pregnancy complication compared to moderate-high levels (Table 3). Although, a 56\% decreased risk for GDM was observed in those with low-moderate levels of standardised vitamin $\mathrm{D}$ when compared to moderate-high levels for women carrying a female fetus (aRR: 0.44; 95\% CI: 0.20, 0.97). Similar results were observed when vitamin $\mathrm{D}$ status was based on clinical definitions of deficiency (Additional file 1: Table S1).

\section{Discussion}

This study adds to the current body of literature on vitamin D status in a population of pregnant Australian and New Zealand women and provides insight into normal circulating levels of $25(\mathrm{OH}) \mathrm{D}$ in early pregnancy. It is the largest prospective cohort study to assess vitamin $\mathrm{D}$ status within the international SCOPE cohort, comparing and combining two distinct populations of pregnant women living at similar latitude and provides a greater understanding of vitamin D deficiency and the risk of adverse pregnancy outcomes. We found, despite being at similar latitudes, circulating $25(\mathrm{OH}) \mathrm{D}$ was different between women recruited in Adelaide compared to women recruited in Auckland. This was independent of diet and lifestyles factors including BMI and SEI and highlights the difficulty in understanding the role of vitamin $D$ in pregnancy in human cohort studies. However, there was a protective association of having high vitamin $\mathrm{D}$ at 15 \pm 1 weeks' gestation and GDM once standardised based on month serum was sampled. Furthermore, there may be possible fetal sex specific differences in vitamin D status worth considering in future studies.

Despite the similar latitudes of Adelaide and Auckland (Adelaide: $34.93^{\circ} \mathrm{S}$ and Auckland $36.85^{\circ} \mathrm{S}$ ), serum $25(\mathrm{OH}) \mathrm{D}$ was lower in the women recruited in Adelaide. Given the significant number of characteristic and lifestyle differences between the two populations, this is not overly surprising. Previous studies have shown a positive association between socioeconomic status and vitamin D in both pregnant and non-pregnant women [36, 37]. The lower SEI of the Adelaide women could therefore make them more susceptible to lower circulating $25(\mathrm{OH}) \mathrm{D}$ because of factors relating to disadvantage. Furthermore, increased BMI is known to be associated with reduced serum 25(OH)D [38-40] as adipose tissue is thought to sequester $25(\mathrm{OH}) \mathrm{D}$ [41]. However, after adjusting for factors shown to be associated with vitamin $\mathrm{D}$ status including BMI and recreational walking, serum $25(\mathrm{OH}) \mathrm{D}$ remained significantly lower in the women 


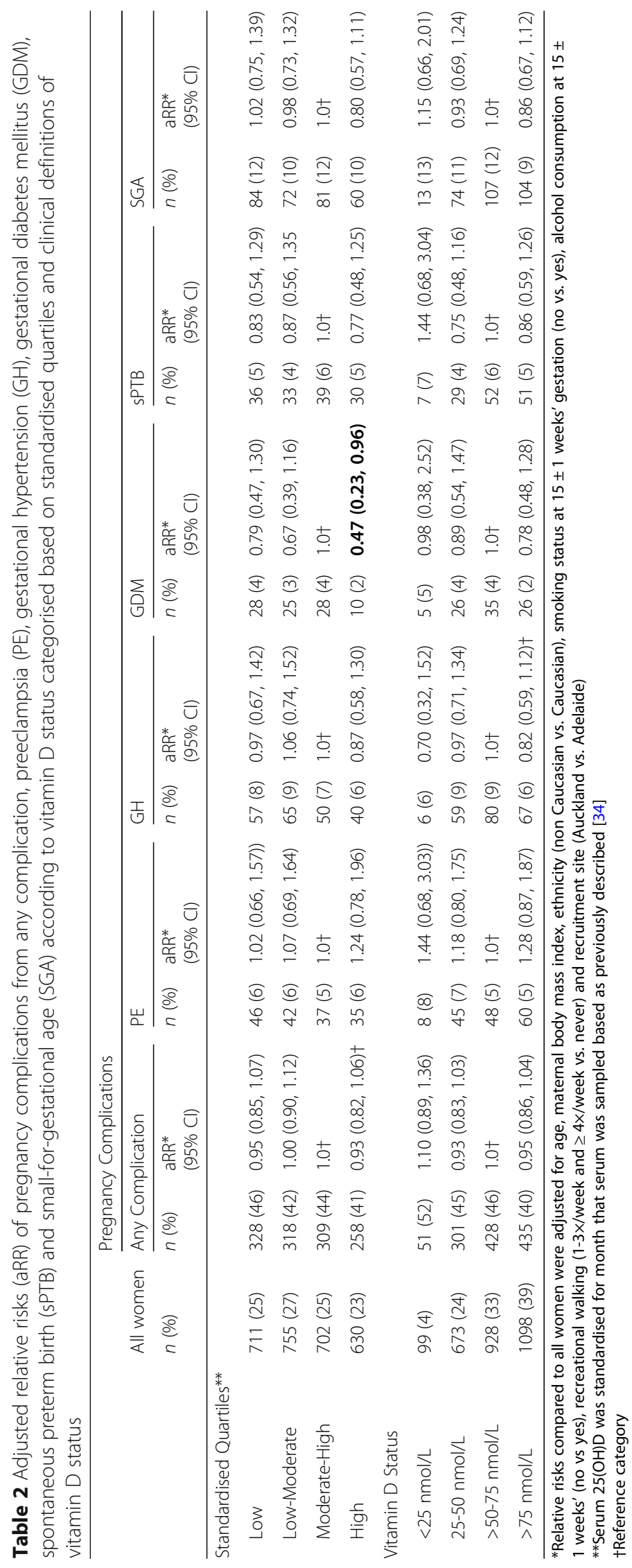




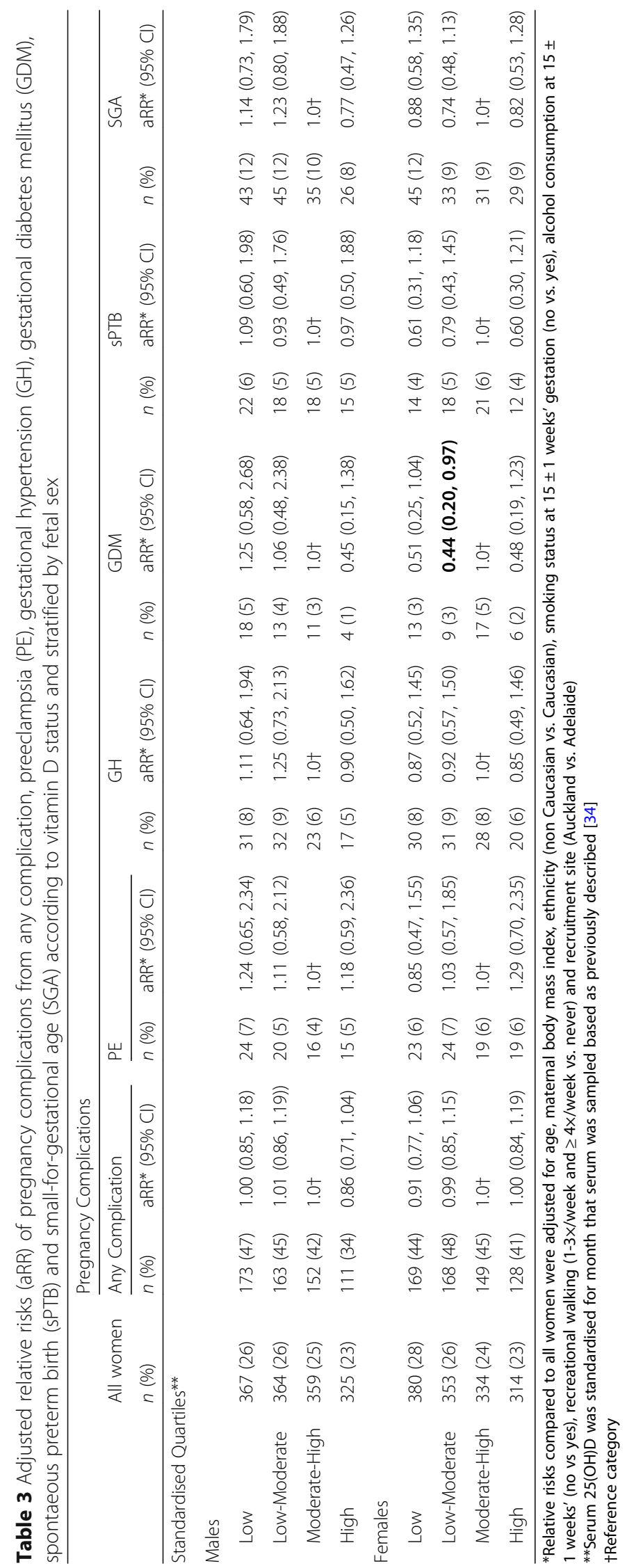


recruited in Adelaide suggesting the influence of other factors not measured as part of SCOPE for example, hours spent outside in the sun. As indicated by the seasonal variation in serum $25(\mathrm{OH}) \mathrm{D}$, amongst women recruited in Adelaide, vitamin D status declined significantly from February to April whilst in the women recruited in Auckland, serum 25(OH)D in March and April remained elevated before declining.

Vitamin D deficiency has previously been associated with insulin resistance and type 2 diabetes given its role in supporting insulin secretion and pancreatic $\beta$-cell function [42]. Furthermore, inverse relationships between serum 25(OH)D and both fasting glucose and fasting insulin have been shown during pregnancy indicating poorer glycaemic control $[19,43]$. Therefore, the protective role of high $25(\mathrm{OH}) \mathrm{D} 15 \pm 1$ weeks' gestation against GDM, as seen with a decreased risk of GDM in women within the 'high' quartile of standardised vitamin D compared to moderate-high, is consistent with knowledge about vitamin $\mathrm{D}$ and diabetes. This is also consistent with another study that observed an increased risk of GDM with vitamin D deficiency in early pregnancy (aOR: 3.40; 95\% CI: 2.03-4.98 [17]) and offers potential physiological connections between vitamin $\mathrm{D}$ status and the progression of insulin resistance in pregnant women. Furthermore, studies have shown that vitamin D supports early placental development $[44,45]$ in which, abnormal placentation can be a characteristic of a number of pregnancy complications including GDM, PE, sPTB and SGA [46].

The placenta expresses all the necessary components to convert $25(\mathrm{OH}) \mathrm{D}$ to the active form and thus utilise active vitamin $\mathrm{D}$ either locally or in a paracrine manner $[45,47]$. Vitamin D metabolism in the placenta has been shown to be influenced by testosterone production and thus varies by fetal sex [35]. Furthermore, sex specific differences in pregnancy outcome have also been reported whereby the risk of sPTB, PE and GDM are all higher in pregnancies with a male fetus [48-50]. In this study, we observed marginal sex-specific differences between early pregnancy vitamin D status and pregnancy outcome where by high vitamin $\mathrm{D}$ status and carrying a male fetus was moderately associated with decreasing the risk of having any pregnancy complication. Conversely, high vitamin D status and carrying a female fetus was not associated with changing the risk of having any pregnancy complication. Indeed, for the risk of GDM an opposite effect of vitamin D status in early pregnancy was observed depending on fetal sex. This is similar to that which has previously been shown in the relationship between vitamin $\mathrm{D}$ status at $\leq 26$ weeks' gestation and placental pathology in pregnancy [51] suggesting that male and female fetuses respond differently to maternal vitamin D status.
Lack of statistically significant associations with other pregnancy complications may reflect the fact that this was a largely vitamin D-replete population ( $>72 \%$ with serum $25(\mathrm{OH}) \mathrm{D}>50 \mathrm{nmol} / \mathrm{L}$ ) likely due to their residence latitude as low serum $25(\mathrm{OH}) \mathrm{D}$ was found in the SCOPE Ireland cohort [52]. Indeed many of the studies that have assessed the association between vitamin D status and adverse pregnancy outcome that have reported statistically significant differences have been in populations with higher rates of vitamin D deficiency $[2,4]$. High dose (> $2000 \mathrm{IU})$ vitamin $\mathrm{D}$ supplementation is associated with decreasing risk of pregnancy complications [23-25]. However, routine vitamin D supplementation did not occur during the time period the women in the current study were recruited. Furthermore, multivitamin supplements available during the study period contained very little (maximum $50 \mathrm{IU}$ ), if any, vitamin $\mathrm{D}$ and thus are an unlikely source of variation within the population. Inconsistencies in the literature may also reflect other causative factors in which vitamin $\mathrm{D}$ is a mediator. For example, active vitamin D (1,25-dihydroxyvitamin $\mathrm{D}_{3}$ ) is the principal hormone that regulates calcium absorption within the intestine [53] and is integral to maintaining calcium homeostasis. During gestation, fetal demand for calcium increases and it is imperative that maternal vitamin $\mathrm{D}$ status remain adequate to support increased calcium absorption from the gut [54]. Therefore, vitamin $\mathrm{D}$ status may be important in populations where dietary calcium intake is low which is unlikely in the population of women studied here.

\section{Conclusions}

In conclusion, once standardised against month of sampling, we demonstrate a protective effect of high vitamin D with GDM. However, differences in vitamin D status between the women recruited in Adelaide and those recruited in Auckland reflect obvious difficulties in studying how vitamin D may support healthy pregnancies. A possible connection between fetal sex, vitamin D status and pregnancy complications reveals further questions and encourages continual research and discussion into the role of vitamin D in pregnancy, particularly in vitamin D replete populations.

\section{Additional file}

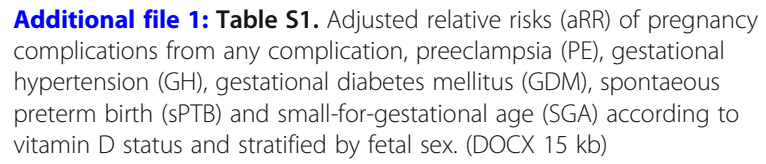

\section{Abbreviations}

25(OH)D : 25-hydroxy vitamin D; aRR : adjusted risk ratio; BMl: body mass index; Cl: confidence interval; GDM: gestational diabetes mellitus;

GH: gestational hypertension; PE: preeclampsia; SCOPE: SCreening fOr Pregnancy Endpoints; SEl: socioeconomic index; SGA: small for gestational age; sPTB: spontaneous preterm birth 


\section{Acknowledgements}

We would like to thank Denise Healy for coordinating the Adelaide cohort and Rennae Taylor for co-ordinating the Auckland SCOPE cohort Rebecca Sawyer (University of South Australia) for assistance in performing serum 25(OH)D analyses.

\section{Funding}

This work was supported by a National Health and Medical Research Council (NHMRC) Project grant awarded to CTR, PHA and GAD (GNT1020754). CTR was supported by an NHMRC Senior Research Fellowship (GNT1020749) and a Lloyd Cox Professorial Research Fellowship, University of Adelaide. PHA is supported by a NHMRC Career Development Award (GNT1051858). LEG is supported by an NHMRC Early Career Fellowship (APP 1070421). The Australian SCOPE study was funded by the Premier's Science and Research Fund, South Australian Government (https://statedevelopment.sa.gov.au/ science/premiers-research-and-industry-fund). The New Zealand SCOPE study was funded by the New Enterprise Research Fund, Foundation for Research Science and Technology; Health Research Council (04/198); Evelyn Bond Fund, Auckland District Health Board Charitable Trust. RLW is supported by an Australian Postgraduate Award.

\section{Availability of data and materials}

The datasets used and/or analysed during the current study are available from the corresponding author on reasonable request. The SCOPE database is provided and maintained by MedSciNet AB (https://medscinet.com).

\section{Authors' contributions}

AJL, PHA, GAD, LM and CTR contributed to the concept and design of this vitamin D association study. GAD, LM and CTR contributed to the design and supervision of the SCOPE study. AJL performed the experiments. RLW and SYL performed the statistical analyses. RLW, PHA, LEG, GAD, TBM and CTR interpreted the data. RLW wrote the manuscript supported by JAG, PEV, LEG and TBM. All authors critically revised the manuscript and approved the final version.

\section{Ethics approval and consent to participate}

This study was approved by the relevant human ethics committees and all participants provided written informed consent (Adelaide: Central Northern Adelaide Health Service Ethics of Human Research Committee on 2 September 2005, ethics number REC 1714/5/2008 and Auckland: Northern Region Ethics Committee on 23 April 2003, ethics number AKX/02/00/364).

\section{Consent for publication}

\section{Not applicable.}

\section{Competing interests}

The authors declare that they have no competing interests.

\section{Publisher's Note}

Springer Nature remains neutral with regard to jurisdictional claims in published maps and institutional affiliations.

\section{Author details \\ ${ }^{1}$ Robinson Research Institute, University of Adelaide, Adelaide, South Australia, Australia. ${ }^{2}$ Adelaide Medical School, University of Adelaide, Adelaide, South Australia, Australia. ${ }^{3}$ School of Pharmacy and Medical Sciences, Division of Health Sciences, University of South Australia, Adelaide, South Australia, Australia. ${ }^{4}$ University Medical Center Groningen, University of Groningen, Groningen, The Netherlands. ${ }^{5}$ Department of Obstetrics and Gynaecology, University of Auckland, Auckland, New Zealand. 'Women's and Children's Division, Lyell McEwin Hospital, Elizabeth Vale, South Australia, Australia. 'Waite Research Institute \& School of Agriculture, Food and Wine, University of Adelaide, Adelaide, South Australia, Australia.}

\section{Received: 11 October 2017 Accepted: 7 June 2018}

\section{Published online: 20 June 2018}

\section{References}

1. Nowson CA, McGrath JJ, Ebeling PR, Haikerwal A, Daly RM, Sanders KM, Seibel MJ, Mason RS. Vitamin D and health in adults in Australia and New Zealand: a position statement. Med J Aust. 2012;196(11):686-7.
2. Aghajafari F, Nagulesapillai T, Ronksley PE, Tough SC, O'Beirne M, Rabi DM Association between maternal serum 25-hydroxyvitamin D level and pregnancy and neonatal outcomes: systematic review and meta-analysis of observational studies. BMJ. 2013;346:f1169.

3. Chowdhury R, Kunutsor S, Vitezova A, Oliver-Williams C, Chowdhury S, Kiefte-de-Jong JC, Khan H, Baena CP, Prabhakaran D, Hoshen MB, et al. Vitamin $D$ and risk of cause specific death: systematic review and metaanalysis of observational cohort and randomised intervention studies. BMJ. 2014;348:g1903.

4. Hollis BW, Wagner CL. Vitamin D and pregnancy: skeletal effects, nonskeletal effects, and birth outcomes. Calcif Tissue Int. 2013;92(2):128-39.

5. Christesen HT, Falkenberg T, Lamont RF, Jorgensen JS. The impact of vitamin D on pregnancy: a systematic review. Acta Obstet Gynecol Scand. 2012;91(12):1357-67.

6. Urrutia RP, Thorp JM. Vitamin D in pregnancy: current concepts. Curr Opin Obstet Gynecol. 2012;24(2):57-64.

7. Paxton GA, Teale GR, Nowson CA, Mason RS, McGrath JJ, Thompson MJ, Siafarikas A, Rodda CP, Munns CF. Vitamin D and health in pregnancy, infants, children and adolescents in Australia and New Zealand: a position statement. Med J Aust. 2013;198(3):142-3.

8. Grover SR, Morley R. Vitamin D deficiency in veiled or dark-skinned pregnant women. Med J Aust. 2001;175(5):251-2.

9. Bowyer L, Catling-Paull C, Diamond T, Homer C, Davis G, Craig ME. Vitamin D, PTH and calcium levels in pregnant women and their neonates. Clin Endocrinol. 2009;70(3):372-7.

10. Judkins A, Eagleton C. Vitamin D deficiency in pregnant New Zealand women. N Z Med J. 2006;119(1241):U2144.

11. Teale GR, Cunningham CE. Vitamin D deficiency is common among pregnant women in rural Victoria. Aust N Z J Obstet Gynaecol. 2010; 50(3):259-61.

12. Davies-Tuck M, Yim C, Knight M, Hodges R, Doery JC, Wallace E. Vitamin D testing in pregnancy: does one size fit all? Aust N Z J Obstet Gynaecol. 2015;55(2):149-55.

13. Perampalam S, Ganda K, Chow KA, Opie N, Hickman PE, Shadbolt B, Hennessy A, Grunstein H, Nolan CJ. Vitamin D status and its predictive factors in pregnancy in 2 Australian populations. Aust N Z J Obstet Gynaecol. 2011;51(4):353-9.

14. Mirzakhani H, Litonjua AA, McElrath TF, O'Connor G, Lee-Parritz A, Iverson R, Macones G, Strunk RC, Bacharier LB, Zeiger R, et al. Early pregnancy vitamin $\mathrm{D}$ status and risk of preeclampsia. J Clin Invest. 2016;126(12):4702-15

15. McDonnell SL, Baggerly KA, Baggerly CA, Aliano JL, French CB, Baggerly LL, Ebeling MD, Rittenberg CS, Goodier CG, Mateus Nino JF, et al. Maternal $25(\mathrm{OH}) \mathrm{D}$ concentrations $>/=40 \mathrm{ng} / \mathrm{mL}$ associated with $60 \%$ lower preterm birth risk among general obstetrical patients at an urban medical center. PLoS One. 2017;12(7):e0180483.

16. Wagner CL, Baggerly C, McDonnell S, Baggerly KA, French CB, Baggerly L, Hamilton SA, Hollis BW. Post-hoc analysis of vitamin D status and reduced risk of preterm birth in two vitamin D pregnancy cohorts compared with South Carolina March of Dimes 2009-2011 rates. J Steroid Biochem Mol Biol. 2016;155(Pt B):245-51.

17. Xu C, Ma HH, Wang Y. Maternal early pregnancy plasma concentration of 25-Hydroxyvitamin D and risk of gestational diabetes mellitus. Calcif Tissue Int. 2018;102(3):280-6.

18. Schneuer FJ, Roberts CL, Guilbert C, Simpson JM, Algert CS, Khambalia AZ, Tasevski V, Ashton AW, Morris JM, Nassar N. Effects of maternal serum 25hydroxyvitamin $D$ concentrations in the first trimester on subsequent pregnancy outcomes in an Australian population. Am J Clin Nutr. 2014; 99(2):287-95.

19. Clifton-Bligh RJ, McElduff P, McElduff A. Maternal vitamin D deficiency, ethnicity and gestational diabetes. Diabet Med. 2008;25(6):678-84

20. Boyle VT, Thorstensen EB, Mourath D, Jones MB, McCowan LM, Kenny LC, Baker PN. The relationship between 25-hydroxyvitamin D concentration in early pregnancy and pregnancy outcomes in a large, prospective cohort. $\mathrm{Br}$ J Nutr. 2016;116(8):1409-15.

21. Martin CA, Gowda U, Renzaho AM. The prevalence of vitamin D deficiency among dark-skinned populations according to their stage of migration and region of birth: a meta-analysis. Nutrition. 2016;32(1):21-32.

22. Christakos S, Dhawan P, Verstuyf A, Verlinden L, Carmeliet G. Vitamin D: metabolism, molecular mechanism of action, and pleiotropic effects. Physiol Rev. 2016;96(1):365-408. 
23. Hollis BW, Johnson D, Hulsey TC, Ebeling M, Wagner CL. Vitamin D supplementation during pregnancy: double-blind, randomized clinical tria of safety and effectiveness. J Bone Miner Res. 2011;26(10):2341-57.

24. Sablok A, Batra A, Thariani K, Batra A, Bharti R, Aggarwal AR, Kabi BC, Chellani H. Supplementation of vitamin $D$ in pregnancy and its correlation with feto-maternal outcome. Clin Endocrinol. 2015;83(4):536-41.

25. Wagner $C L$, McNeil RB, Johnson DD, Hulsey TC, Ebeling $M$, Robinson C, Hamilton SA, Hollis BW. Health characteristics and outcomes of two randomized vitamin D supplementation trials during pregnancy: a combined analysis. J Steroid Biochem Mol Biol. 2013;136:313-20.

26. Wagner $\mathrm{CL}$, Baggerly C, McDonnell SL, Baggerly L, Hamilton SA, Winkler J, Warner G, Rodriguez C, Shary JR, Smith PG, et al. Post-hoc comparison of vitamin $D$ status at three timepoints during pregnancy demonstrates lower risk of preterm birth with higher vitamin D closer to delivery. J Steroid Biochem Mol Biol. 2015;148:256-60.

27. Cluse ZN, Fudge AN, Whiting MJ, McWhinney B, Parkinson I, O'Loughlin PD. Evaluation of 25-hydroxy vitamin D assay on the immunodiagnostic systems iSYS analyser. Ann Clin Biochem. 2012;49(Pt 2):159-65.

28. Kenny LC, Black MA, Poston L, Taylor R, Myers JE, Baker PN, McCowan LM, Simpson NA, Dekker GA, Roberts $C T$, et al. Early pregnancy prediction of preeclampsia in nulliparous women, combining clinical risk and biomarkers: the Screening for pregnancy endpoints (SCOPE) international cohort study. Hypertension. 2014;64(3):644-52.

29. McCowan LM, Roberts $C T$, Dekker GA, Taylor RS, Chan EH, Kenny LC, Baker PN, Moss-Morris R, Chappell LC, North RA. Risk factors for smallfor-gestational-age infants by customised birthweight centiles: data from an international prospective cohort study. BJOG. 2010;117(13): 1599-607.

30. Davis P, McLeod K, Ransom M, Ongley P, Pearce N, Howden-Chapman P. The New Zealand socioeconomic index: developing and validating an occupationally-derived indicator of socio-economic status. Aust N Z J Public Health. 1999;23(1):27-33.

31. McCowan LM, Dekker GA, Chan E, Stewart A, Chappell LC, Hunter M, MossMorris R, North RA. Spontaneous preterm birth and small for gestational age infants in women who stop smoking early in pregnancy: prospective cohort study. BMJ. 2009;338:b1081.

32. International Association of $D$, pregnancy study groups consensus $P$ Metzger BE, Gabbe SG, Persson B, Buchanan TA, Catalano PA, Damm P, dyer AR, Leiva a et al: International association of diabetes and pregnancy study groups recommendations on the diagnosis and classification of hyperglycemia in pregnancy. Diabetes Care 2010, 33(3): 676-682.

33. Team RDC: R: A Language and Environment for Statistical Computing In. Vienna, Austria: R Foundation for Statistical Computing; 2011.

34. Travis RC, Crowe FL, Allen NE, Appleby PN, Roddam AW, Tjonneland A, Olsen A, Linseisen J, Kaaks R, Boeing H, et al. Serum vitamin D and risk of prostate cancer in a case-control analysis nested within the European prospective investigation into Cancer and nutrition (EPIC). Am J Epidemiol. 2009;169(10):1223-32.

35. Olmos-Ortiz A, Garcia-Quiroz J, Lopez-Marure R, Gonzalez-Curiel I, RivasSantiago B, Olivares A, Avila E, Barrera D, Halhali A, Caldino F, et al. Evidence of sexual dimorphism in placental vitamin D metabolism: testosterone inhibits calcitriol-dependent cathelicidin expression. J Steroid Biochem Mol Biol. 2016;163:173-82.

36. Rabenberg M, Scheidt-Nave C, Busch MA, Rieckmann N, Hintzpeter B, Mensink GB. Vitamin D status among adults in Germany-results from the German health interview and examination survey for adults (DEGS1). BMC Public Health. 2015;15:641.

37. Rodriguez A, Santa Marina L, Jimenez AM, Esplugues A, Ballester F, Espada M, Sunyer J, Morales E. Vitamin D status in pregnancy and determinants in a southern European cohort study. Paediatr Perinat Epidemiol. 2016;30(3):217-28,

38. Arunabh S, Pollack S, Yeh J, Aloia JF. Body fat content and 25hydroxyvitamin D levels in healthy women. J Clin Endocrinol Metab. 2003; 88(1):157-61.

39. Bodnar LM, Catov JM, Roberts JM, Simhan HN. Prepregnancy obesity predicts poor vitamin D status in mothers and their neonates. J Nutr. 2007; 137(11):2437-42.

40. McKinney K, Breitkopf CR, Berenson AB. Association of race, body fat and season with vitamin $D$ status among young women: a cross-sectional study. Clin Endocrinol. 2008;69(4):535-41.
41. Wortsman J, Matsuoka LY, Chen TC, Lu Z, Holick MF. Decreased bioavailability of vitamin D in obesity. Am J Clin Nutr. 2000;72(3):690-3.

42. Palomer X, Gonzalez-Clemente JM, Blanco-Vaca F, Mauricio D. Role of vitamin $\mathrm{D}$ in the pathogenesis of type 2 diabetes mellitus. Diabetes Obes Metab. 2008;10(3):185-97.

43. Lau SL, Gunton JE, Athayde NP, Byth K, Cheung NW. Serum 25hydroxyvitamin $\mathrm{D}$ and glycated haemoglobin levels in women with gestational diabetes mellitus. Med J Aust. 2011;194(7):334-7.

44. Novakovic B, Sibson M, Ng HK, Manuelpillai U, Rakyan V, Down T, Beck S, Fournier T, Evain-Brion D, Dimitriadis E, et al. Placenta-specific methylation of the vitamin D 24-hydroxylase gene: implications for feedback autoregulation of active vitamin D levels at the fetomaternal interface. J Biol Chem. 2009;284(22):14838-48.

45. Fischer D, Schroer A, Ludders D, Cordes T, Bucker B, Reichrath J, Friedrich M. Metabolism of vitamin D3 in the placental tissue of normal and preeclampsia complicated pregnancies and premature births. Clin Exp Obstet Gynecol. 2007;34(2):80-4.

46. Brosens I, Pijnenborg R, Vercruysse L, Romero R. The "great obstetrical syndromes" are associated with disorders of deep placentation. Am J Obstet Gynecol. 2011;204(3):193-201.

47. Shin JS, Choi MY, Longtine MS, Nelson DM. Vitamin D effects on pregnancy and the placenta. Placenta. 2010;31(12):1027-34.

48. Aibar L, Puertas A, Valverde M, Carrillo MP, Montoya F. Fetal sex and perinatal outcomes. J Perinat Med. 2012;40(3):271-6.

49. Melamed N, Yogev Y, Glezerman M. Fetal gender and pregnancy outcome. J Matern Fetal Neonatal Med. 2010:23(4):338-44

50. Verburg PE, Tucker G, Scheil W, Erwich JJ, Dekker GA, Roberts CT. Sexual dimorphism in adverse pregnancy outcomes - a retrospective Australian population study 1981-2011. PLoS One. 2016;11(7):e0158807.

51. Gernand AD, Bodnar LM, Klebanoff MA, Parks WT, Simhan HN. Maternal serum 25-hydroxyvitamin D and placental vascular pathology in a multicenter US cohort. Am J Clin Nutr. 2013;98(2):383-8.

52. Kiely ME, Zhang JY, Kinsella M, Khashan AS, Kenny LC. Vitamin D status is associated with uteroplacental dysfunction indicated by pre-eclampsia and small-for-gestational-age birth in a large prospective pregnancy cohort in Ireland with low vitamin D status. Am J Clin Nutr. 2016;104(2):354-61.

53. Christakos S, Dhawan P, Porta A, Mady LJ, Seth T. Vitamin D and intestinal calcium absorption. Mol Cell Endocrinol. 2011;347(1-2):25-9.

54. Kovacs CS. Calcium and bone metabolism disorders during pregnancy and lactation. Endocrinol Metab Clin N Am. 2011;40(4):795-826.

\section{Ready to submit your research? Choose BMC and benefit from:}

- fast, convenient online submission

- thorough peer review by experienced researchers in your field

- rapid publication on acceptance

- support for research data, including large and complex data types

- gold Open Access which fosters wider collaboration and increased citations

- maximum visibility for your research: over $100 \mathrm{M}$ website views per year

At BMC, research is always in progress.

Learn more biomedcentral.com/submissions 